\title{
A abrangência da garantia constitucional da amplitude de defesa e a sua efetiva aplicação prática durante os plantões policiais - uma reflexão necessária
}

\author{
André Luis Jardini Barbosa ${ }^{1}$
}

\begin{abstract}
Resumo: Praticado o delito, faz-se instaurada a persecução penal. Esse é o poder-dever que toca ao Estado, em caráter exclusivo, para colher todos os elementos que sirvam, num primeiro instante, à comprovação tanto da efetiva ocorrência como também a indicação, ainda precária, de que seja o seu autor. Tudo como forma de assegurar, pela via do processo - sua segunda fase -, venha ele a ser responsabilizado penalmente, assegurando-se o âmbito das relações sociais. A persecução penal encontra, no inquérito policial, o seu grande protagonista. Sobre esse procedimento administrativo, cujo manejo constitui a atribuição exclusiva dos órgãos de polícia judiciária, contudo, pesam dúvidas no sentido da necessidade de efetiva observância da garantia constitucional da ampla defesa. Considerando-se que a grande maioria dos inquéritos policiais se inicia pelo auto de prisão em flagrante, os quais, por sua vez, são elaborados durante os plantões policiais, e, portanto, fora do chamado expediente forense, é preciso questionar se não ocorreria, nesses casos, uma aparente violação da garantia mencionada. Nesse contexto, procurar-se-á analisar, também, até que ponto a presença efetiva da defensoria pública nas sedes daqueles plantões policiais não viria em socorro das pessoas que se veem imersas naquela realidade.
\end{abstract}

Palavras-chave: Princípio da ampla defesa. Persecução penal. Investigação policial. Inquérito policial. Defensoria pública.

\begin{abstract}
As soon as a crime has been committed, the accusatory procedure is instituted. It is power-duty of the State, in an exclusive way, to collect all the elements that serve to prove the occurrence of the fact and, also, the circumstantial evidence of its author. This is necessary to ensure, in a second stage, the due process to condemn the criminally responsible, keeping the maintenance of a peaceful society. The criminal investigation is the main instrument for police inquest, and with regard to the latter, which is managed exclusively by the judicial police in Brazil, however, there are doubts of its effectiveness compliance with the constitutional guarantee of the legal defense. Considering that the vast majority of police inquiries are initiated by the "flagrante delicto" arrest,
\end{abstract}

\footnotetext{
${ }^{1}$ Delegado de Polícia e professor universitário da Faculdade Dr. Francisco Maeda (FAFRAM) e da Faculdade de Direito de Franca (FDF). Doutorando em Direito pela Faculdade Autônoma de Direito/FADISP - campus de São Paulo. Mestre em Direito pela UNESP/Franca. Especialista em Direito Processual Penal pela Escola Paulista de Magistratura/EPM. E-mail: draljbarbosa@yahoo.com.br
} 
which are ratified by the chief of police on duty, so off the record of forensic expedient, giving reasons to question if this constitutional principle is sincerely attended. In this context, this work aims to analyze the role of public defenders' presence at the police station as a guarantee of legal defense for those subjected to the police action.

Keywords: Legal Defense. Accusatory Procedure. Criminal investigation; Police inquest. Public Defense.

\section{Introdução}

Dentre os vários direitos e garantias enunciados ${ }^{2}$ no texto da Constituição Federal vigente, chama atenção aquele que determina que devam ser assegurados aos litigantes em processo judicial ou administrativo, e aos acusados em geral o contraditório e a ampla defesa, com os meios e os recursos a ela inerentes ${ }^{3}$.

O referido dispositivo, embora aparentemente singelo em seu enunciado, traz em si duas grandes conquistas dos cidadãos frente ao arbítrio estatal. Uma delas diz respeito ao fato de possibilitar que aquele que, de qualquer modo, venha a litigar com o Estado, tenha assegurado o conhecimento das razões de que se possa valer aquele ente como forma de demonstrar o direito que invoca. Mas não apenas isso. Esse conhecimento deverá ser, também, prévio, de modo a evitar surpresas e dissabores ao particular, e, com isso, garantir-lhe a plena igualdade de condições no transcorrer da, nem sempre célere, relação jurídica processual.

Uma vez cientificada a parte acerca dos atos e dos termos do processo, surge para ela o direito de, querendo, valer-se de todos os meios e formas dispostos pelo ordenamento jurídico a fim de que sejam demonstradas as suas razões e, com isso, ao menos possibilitar a desconstituição da argumentação trazida em seu desfavor.

\footnotetext{
2 E também não nos descuidando de considerar a existência de outros direitos e garantias fundamentais não expressos ou implícitos.

${ }^{3}$ Art. 5o., inc. LV, da Constituição Federal (BRASIL, 1988).
} 
Os conceitos acima apresentados traduzem o que a doutrina denomina contraditório e ampla defesa, acerca dos quais leciona Antonio Scarance Fernandes, citando Joaquim Canuto Mendes de Almeida:

São elementos essenciais do contraditório a necessidade de informação e a possibilidade de reação. Entre nós, tem-se, em regra, adotado noção clássica de JOAQUIM CANUTO MENDES DE ALMEIDA, que abrange esses dois elementos e define o contraditório como "a ciência bilateral dos atos e termos processuais e possibilidade de contrariá-los" (ALMEIDA apud FERNANDES, 2010, p. 57).

Muito embora a leitura desatenta do dispositivo constitucional mencionado possa indicar certa dose de sinonímia entre as expressões, a verdade é que elas em nada se confundem, sendo diversos os seus conceitos e âmbitos de incidência.

Não se pode descuidar de considerar, todavia, o fato de elas resguardarem entre si uma relação de complementaridade, podendo-se afirmar que seja uma decorrência lógica da outra.

A esse respeito, aliás, afirma Alexandre de Moraes:

Por ampla defesa entende-se o asseguramento que é dado ao réu de condições que lhe possibilitem trazer para o processo todos os elementos tendentes a esclarecer a verdade ou mesmo de omitir-se ou calar-se, se entender necessário, enquanto o contraditório é a própria exteriorização da ampla defesa, impondo a condução dialética do processo (par conditio), pois a todo ato produzido pela acusação caberá igual direito da defesa de opor-se-lhe ou de dar-lhe uma versão que melhor lhe apresente, ou, ainda, de fornecer uma interpretação jurídica diversa daquela feita pelo autor (MORAES, 2011, p. 113).

O presente trabalho restringir-se-á à análise da garantia constitucional da amplitude de defesa. Pretende-se, aqui, discorrer acerca de seu significado e de sua real amplitude, a qual, como se viu, abrange os litigantes em processo judicial ou administrativo e aos acusados em geral. 
Nesse contexto, ter-se-á como foco, especificamente, a pessoa do acusado, indivíduo sobre o qual recai a mão forte do Estado, em especial, no transcorrer da fase preliminar da persecução penal.

Esses indivíduos, quase sempre pessoas necessitadas - e, portanto, hipossuficientes, econômica e/ou juridicamente -, se veem muitas vezes imersos na realidade cotidiana dos plantões policiais distribuídos entre os mais variados rincões do país, sem o necessário respaldo do aparato estatal defensivo, encontrando-se, com isso, entregues à própria sorte.

Não deve ser esquecido que as atividades desenvolvidas em sede de plantões policiais se realizam fora do horário de expediente forense e, portanto, sem que estejam presentes os chamados atores processuais, exceção feita, obviamente, à Autoridade Policial e seus agentes.

Essas pessoas encontram-se, por assim dizer, alheias ao âmbito de proteção da chamada ampla defesa, cláusula constitucional fundamental que se traduz - ou ao menos se deveria traduzir - em verdadeira expressão da cidadania.

Passa a ganhar relevo, nesse contexto, o questionamento sobre a atuação dos agentes integrantes da defensoria pública.

Essa é a instituição a quem é dotada a atribuição constitucional de zelar, em todos os graus, judicial e extrajudicialmente, pelos direitos individuais e coletivos, de forma integral e gratuita dos necessitados ${ }^{4}$.

Ocorre, todavia, que a ausência desses profissionais do direito na sede dos plantões policiais tem transformado a garantia constitucional da ampla defesa em uma defesa técnica ofertada apenas em horário comercial, já em fase judicial do procedimento - mesma oportunidade em que tomam conhecimento da acusação o Poder Judiciário e o Ministério Público -, no mais das vezes, sem que tenha ao menos havido o necessário e o imprescindível contato, além de uma entrevista prévia dos defensores públicos para com a pessoa que virá a ser por eles representada. Percebe-se,

\footnotetext{
${ }^{4}$ Art. 134, caput, da Constituição Federal (BRASIL, 1988).
} 
com isso, uma afronta ao comando constitucional, algo com o que não se deve coadunar e que justifica a relevância da análise procedida neste estudo.

\section{O crime como fenômeno social}

São vários os autores e as teorias que procuram discutir as razões que levam os indivíduos a viver em coletividade. A despeito da inteligência dos argumentos expendidos por cada uma delas, a verdade é que essa parece ser uma verdadeira marca da nossa espécie. A vida em coletividade, por envolver um complexo de interações individuais, nem sempre estará isenta de se fazer acompanhada por uma série de inconvenientes. Decorrem dessas condutas os conflitos de interesse, os quais, se não devidamente solucionados, poderão gerar a instabilidade das relações entre os indivíduos e até mesmo inviabilizar o próprio desenvolvimento do homem em sociedade.

Nasce daí o Direito, que passa a ser considerado como fator regulamentador das condutas humanas em sociedade ou, como afirmam Georges Abboud, Henrique Garbellini Carnio e Rafael Tomaz de Oliveira:

\footnotetext{
O direito é um fenômeno social. Esta constatação inegável entre os estudiosos do direito. Portanto, se é evidente que o direito seja um fenômeno social, mais especificamente, que fenômeno social é o direito? Historicamente, pode-se afirmar que o direito possui o caráter de regulador das relações humanas. O surgimento das normas jurídicas evidentemente está ligado à ideia de que homem é ser social e que se impõe, para sua convivência com os outros, limitações de sua conduta, interagindo de distintas formas com ações no meio social em que vive (ABBOUD; CARNIO; OLIVEIRA, 2015, p. 85).
}

Muitas vezes, contudo, os indivíduos, mesmo estando as ações devidamente regulamentadas, passam a se comportar de forma contrária ao que lhes são determinados. 
Essas condutas se revelam como atos antissociais ${ }^{5}$, ou simplesmente ilícitos, conforme destaca Fernando de Almeida Pedroso:

\begin{abstract}
A ilicitude se revela pelo antagonismo do comportamento humano com os princípios e emanações defluentes do ordenamento jurídico. Expressa a contrariedade da conduta com os parâmetros e diretrizes estabelecidos para a vida social organizada. Ilicitude, que encontra expressão sinônima em antijuridicidade, traduz a idéia de transgressão ao Direito e desponta como a antítese do correto ou do justo. Denota fato que conturba a harmonia e equilíbrio sociais dentro do ideal da ordem e coesão na vida comunitária (PEDROSO, 2008, p. 47).
\end{abstract}

A esse respeito, merece destaque a doutrina de Luiz Guilherme Marinoni e Sérgio Cruz Arenhart:

\begin{abstract}
Como é necessária a existência de regras jurídicas para a harmônica convivência social, e como pode existir dúvida em torno de sua interpretação, ou mesmo da intenção de desrespeitá-las, podem eclodir no seio da sociedade conflitos de interesses. Como a insatisfação de um interesse - principalmente quando essa insatisfação decorre da resistência de alguém - pode gerar tensão aos contendores e até mesmo tensão social, é importante que os conflitos sejam eliminados e seja encontrada a paz social, escopo do Estado (MARINONI; ARENHART, 2007, p. 31).
\end{abstract}

Necessário mencionar, desde logo, que a grande maioria desses atos resvala no âmbito de proteção meramente disponível dos indivíduos. São condutas que, embora ilícitas, acabam por incidir sobre a esfera de proteção do direito alheio de forma menos sensível. Por essa razão, são mais facilmente solucionáveis. Em geral, caberá às próprias partes envolvidas transacionarem acerca da melhor forma de solução da questão. A atuação do Estado, nesses casos, mostra-se, por assim dizer, excepcional e meramente eventual ${ }^{6}$. Outras vezes, porém, a conduta agressiva à ordem jurídica

\footnotetext{
${ }^{5}$ Deve ser mencionado, desde logo, que será utilizada termo atos, como forma de expressar a conduta humana exteriorizada e tendente a uma determinada finalidade.

6 Essa afirmação parece, contudo, não encontrar o necessário respaldo na realidade judiciaria brasileira, que parece colecionar, a cada dia, um maior número de causas postas à análise dos juízes e dos tribunais. A verdade, porém, é que o processo deve ser compreendido enquanto exceção do sistema, e não a regra como aqui ocorre. Essa é uma cultura que necessita urgentemente ser implementada nos cursos de Direito, afastando-se o futuro profissional da cultura do litígio.
} 
vigente atinge a parcela extremamente sensível do indivíduo que a sofre. Esta passa a ser classificada como crime, atos que, igualmente decorrentes da ação humana, afetam de tal modo o âmbito das relações sociais, que fazem com que, nesses casos, não mais se mostre viável a mera composição entre as partes, sobretudo porque impossível o restabelecimento do estado anterior das coisas.

Pegue-se, a título de exemplo, a conduta daquele que, de forma voluntária e consciente, acaba por tirar a vida de seu semelhante. Nesses casos, não mais será possível e nem ao menos viável a mera recomposição dos danos sofridos pelas partes envolvidas. Não é possível recobrar à vítima o sopro de vida que lhe foi tirado. Quanto aos seus sucessores, o ordenamento jurídico não lhes resguarda uma forma equivalente de compensação pela perda sofrida.

Em casos como tais, a simples atuação das partes envolvidas no litígio já não mais se mostra suficiente a trazer a pacificação social. Ao contrário, acaba por trazer à tona a possibilidade de ocorrência da chamada vingança privada, algo que nem sempre conduz a uma solução razoável e pautada pela proporcionalidade.

Como forma de assegurar uma atuação isenta frente ao interesse das partes, o Estado acaba por outorgar para si a tarefa de, num primeiro instante, identificar o agressor da ordem jurídica, para, em seguida, ao final do procedimento regular previsto em lei para tanto e sempre assegurados os seus direitos e as suas garantias fundamentais, impor-lhe a sanção respectiva. Este, aliás, o objetivo da persecução penal do Estado, atividade hoje entendida enquanto monopólio estatal, e que, pela sua relevância, merecerá tratamento específico no tópico seguinte. 


\section{A atividade de persecução penal do Estado. Objetivos e fases}

Assumido pelo Estado o papel de ente ordenador das condutas individuais em sociedade, compete-lhe verificar se, na realidade cotidiana, o complexo de relações havidas entre os homens se dá dentro daquilo que razoavelmente se espera. Ou seja, se há conformidade entre as condutas individuais e os comandos normativos vigentes.

Uma vez que se vislumbre a possibilidade de que tal não ocorra, estará aquele ente autorizado a agir, como forma de assegurar que os comportamentos individuais se deem de forma não abusiva. Nisso se traduz a própria ideia de poder de polícia estatal, acerca do qual José dos Santos Carvalho Filho revela:

De nossa parte, entendemos que se possa conceituar o poder de polícia como a prerrogativa de direito público que, calcada na lei, autoriza a Administração Pública a restringir o uso e o gozo da liberdade e da propriedade em favor do interesse da coletividade (CARVALHO FILHO, 2009, p. 73).

Trata-se da prerrogativa de que dispõe o Estado para ajustar e condicionar as condutas individuais a um padrão minimamente aceitável, sempre de modo a alcançar o interesse público ${ }^{7}$. Ou, como prefere Celso Antonio Bandeira de Mello:

A atividade estatal de condicionar a liberdade e a propriedade, ajustando-as aos interesses coletivos designa-se "poder de polícia”. A expressão, tomada neste sentido amplo, abrange tanto atos do Legislativo quanto do Executivo. Refere-se, pois, ao complexo de medidas do Estado que delineia a esfera juridicamente tutelada da liberdade e da propriedade dos cidadãos. Por isso, nos Estados Unidos, a voz police power reportase sobretudo às normas legislativas através das quais o Estado regula os direitos privados, constitucionalmente atribuídos aos

\footnotetext{
${ }^{7}$ É sabido que esse poder estatal compreende, na realidade do universo jurídico, a atribuição de uma infinidade de órgãos, sendo admitido falar-se em polícia sanitária, polícia tributária etc. Entretanto, e haja vista a necessidade de delimitação do tema, restringe-se a análise do presente aos órgãos incumbidos da prevenção criminal - polícia administrativa - e da coleta de elementos de informação que irão subsidiar a eventual ação penal - polícia judiciária.
} 
cidadãos, em proveito dos interesses coletivos, como bem anota Caio Tácito (BANDEIRA DE MELLO, 2009, p. 815).

O livre exercício das condutas individuais não é revestido, portanto, de caráter absoluto, devendo estar apegado aos preceitos legais vigentes. Assim, a ação estatal de polícia estará justificada sempre que, de qualquer modo, restar evidenciada a possibilidade de afetação daqueles comandos.

Ou, como explicita Lincoln D’Aquino Filocre:

\begin{abstract}
A sociedade que não proporciona liberdade - direito do homem que reconhece a este o poder de escolha nos diversos campos da vida social - aos seus membros a rigor não se justifica. A liberdade, ainda que não absoluta, é meta e essência da sociedade. São extremos: de um lado, a utópica sociedade perfeita, ou seja, essencialmente democrática, liberal, sem injustiças econômicas, educacionais, de saúde, cultural etc. Nela, a liberdade é absoluta. Do outro lado, a sociedade imperfeita, desigual, não democrática, injusta, repleta dos mais graves vícios econômicos, de educação, de saúde, cultura etc. Nestas, a liberdade é inexistente. Entre os extremos está a sociedade real - lat. reale -, a de fato, a verdadeira ou efetiva, aquela na qual os problemas econômicos, educacionais, de saúde, culturais etc., existem em infinitos níveis intermediários [...] a sociedade real, por seu turno, pode ter maior ou menor segurança pública. Numa sociedade real, a maior segurança pública adequada é aquela compatível com o equilíbrio dinâmico social, ou seja, adequada à convivência social estável (FILOCRE, 2010, p. 41-42)
\end{abstract}

O poder de polícia do Estado pode se exteriorizar de forma preventiva ou repressiva. A primeira, quando anterior à prática do delito. A segunda, por sua vez, pressupondo que tal delito tenha já ocorrido.

A atividade de polícia estatal preventiva compreende, no âmbito do ordenamento jurídico nacional, a atribuição das Polícias Militares e dos Corpos de Bombeiros Militares dos Estados e do Distrito Federal ${ }^{8}$.

É bem verdade que será sempre preferível a atuação policial em caráter preventivo. Reprimir o delito importa reconhecer que o Estado falhou em uma de suas missões essenciais. Equivale dizer que, verificada a prática delitiva, instaura-se uma indesejável sensação de insegurança, a

${ }^{8}$ Art. 144, parágrafo 6o, da Constituição Federal (BRASIL, 1988). 
qual deve ser prontamente combativa, também como forma de pacificar o corpo social.

Nasce para o Estado, com isso, não apenas a faculdade, mas o dever de proceder à colheita dos elementos aptos a demonstrar não apenas a efetiva ocorrência do crime, como também proceder à identificação do seu autor. Confira-se, a propósito, a doutrina de Nestor Távora e Rosmar Rodrigues de Alencar:

Os órgãos incumbidos da Persecução Criminal, em estando presentes os permissivos legais, estão obrigados a atuar. A Persecução Criminal é de ordem pública, e não cabe juízo de conveniência ou oportunidade. Assim, o Delegado de Polícia e o Promotor de Justiça, como regra, estão obrigados a agir, não podendo exercer juízo de conveniência quanto ao início da persecução (TÁVORA; ALENCAR, 2009, p. 48).

Tudo como forma de possibilitar a subsequente apuração da responsabilidade do autor do fato e, se for o caso, a imposição da sanção penal respectiva.

Instaura-se, a partir da prática do delito, a persecução penal - ou persecutio criminis -, atividade que tem por objetivo a perfeita ${ }^{9}$ elucidação do fato e de sua autoria, com vistas à submissão do delinquente a julgamento perante o Poder Judiciário, em procedimento em que lhe sejam assegurados o contraditório e a ampla defesa, com os meios e os recursos a ela inerentes. A doutrina processualista penal brasileira não contempla um conceito do que seja essa atividade. Prefere simplesmente delimitar as suas fases, cada qual afeta a um órgão do Estado, com poderes e atribuições específicas.

Arriscando-me a uma conceituação dessa tão relevante fase, pode-se dizer que a persecução penal ou a etapa de perseguição penal compreende

\footnotetext{
9 A doutrina processualista penal brasileira ainda menciona ser o objetivo do processo penal a reconstrução da verdade material do delito. Sabe-se, porém, que nem sempre isso será possível, até porque a reconstrução dos fatos ocorridos sempre se dará da forma mais próxima possível à realidade. Assim, hoje é correto falar-se em verdade possível.
} 
aquela em que, posteriormente à ocorrência do fato criminoso, tem por objetivo a coleta dos elementos sensíveis deixados pela infração, de modo a indicar tanto a sua efetiva ocorrência - delimitação do fato e de todas as suas circunstâncias -, como também quem seja o seu autor, possibilitando, com isso, a imposição da respectiva responsabilização penal pelo fato praticado.

Da conceituação apresentada, é possível vislumbrar-se as duas fases da persecução penal. A primeira delas, também conhecida como fase preliminar ou extrajudicial, tem por objetivo a coleta dos elementos de informação que se prestarão a subsidiar a convicção dos órgãos acusador e julgador. No ordenamento jurídico brasileiro, essa atividade constitui função própria das Polícias Civis dos Estados e do Distrito Federal e da Polícia Federal ${ }^{10}$.

A segunda fase, por sua vez, tem caráter necessariamente judicial, e terá início a partir do oferecimento da denúncia pelo Ministério Público. É o que salienta Paulo Rangel:

Posto isto, o legislador (na esfera penal) passa a observar a sociedade e percebe que um determinado comportamento deve ser proibido, pois em descompasso com a paz e a tranquilidade social exigidas. Exemplo: matar alguém. Pena: de seis a vinte anos de reclusão. Nesse momento, nasce para todos da sociedade um comportamento proibido: não matar alguém. É uma norma geral e abstrata, que observa a todos, indistintamente. Tício (o famoso meliante) resolve descumprir a norma genérica e abstrata e matar Semprônio. Agora, nasce para o Estado o direito de aplicar a sanção descrita no tipo penal violado (pena de seis a vinte anos de reclusão). Assim, aquela norma que se dirigia a todos indistintamente ( e continua), passa a incidir sobre Tício. Porém, o Estado necessita de órgãos que se incumbam de fazer operar a norma legal, apurando os fatos e todas as suas circunstâncias, bem como garantindo a Tício todos os meios de defesa que um Estado Democrático de Direito possa assegurar-lhe através de um devido processo legal, pois é cediço que nenhuma pena poderá ser imposta ao réu senão por meio de um regular processo (nullum poena sine iudicio). Dessa forma, surge a chamada persecutio criminis, que é exercida pela polícia de atividade judiciaria (através do inquérito policial) e pelo Ministério Público (através da competente ação penal) (RANGEL, 2013, p. 70).

${ }^{10}$ Art. 144, parágrafos 1o. e 4o., da Constituição Federal (BRASIL, 1988). 
Compete-nos, neste estudo, analisar mais de perto a fase preliminar da persecução penal. É nela que reside grande parte das divergências doutrinárias no que toca à necessidade de efetiva aplicação prática da garantia constitucional da ampla defesa.

Adiantando-nos ao raciocínio a ser empreendido no capítulo seguinte, tenho que a posição doutrinária contrária à observância do dispositivo constitucional não se sustenta, sobretudo, porque o texto constitucional se mostra bastante claro nesse sentido.

Atenhamo-nos nesse primeiro instante, pois, sobre a primeira das fases da persecução penal, é nessa etapa que se realiza a atividade de investigação policial ou criminal. Essa se consubstancia no conjunto de procedimentos e de diligências tendentes ao levantamento dos elementos de informação que indicarão quando e como determinado fato ocorreu, bem como quem seja o seu autor.

O ordenamento jurídico brasileiro não prevê, especificamente, um conceito do que seja investigação policial. Ao contrário, prefere o legislador oferecer um rol de providências a serem adotadas pelos órgãos policiais, em cada caso concreto.

Veja-se, por exemplo, o artigo $6^{\circ}$ do Código de Processo Penal (BRASIL, 1941), o qual estabelece ser dever da autoridade policial, dentre outros:

I - dirigir-se ao local, providenciando para que não se alterem o estado e a conservação das coisas, até a chegada dos peritos criminais; II - apreender os objetos que tiverem relação com o fato, após liberados pelos peritos criminais; III - colher todas as provas que servirem para o esclarecimento do fato e suas circunstâncias; IV - ouvir o ofendido; V - ouvir o indiciado; VI - proceder a reconhecimento de pessoas e coisas e as acareações; VII determinar, se for o caso, que se proceda a exame de corpo de delito e a quaisquer outras perícias; VIII - ordenar a identificação do indiciado, respeitados os ditames da Constituição Federal; IX averiguar a vida pregressa do indiciado etc. 
No mesmo sentido, o artigo $3^{\circ}$ da ainda recente Lei $\mathrm{n}^{\circ} 12.850$, de 2 de agosto de 2013, que, dispondo sobre a investigação policial, estabelece a admissibilidade da obtenção da prova por meio de:

I - colaboração premiada; II - captação ambiental de sinais eletromagnéticos, ópticos ou acústicos; III - ação controlada; IV acesso a registros de ligações telefônicas e telemáticas, a dados cadastrais constantes de bancos de dados públicos ou privados e a informações eleitorais ou comerciais; V - interceptação de comunicações telefônicas e telemáticas, nos termos da legislação específica; VI - afastamento dos sigilos financeiro, bancário e fiscal, nos termos da legislação específica; VII - infiltração, por policiais, em atividade de investigação; VIII - cooperação entre instituições e órgãos federais, distritais, estaduais e municipais na busca de provas e informações de interesse da investigação ou da instrução criminal.

$\mathrm{Na}$ medida em que a atividade de investigação tem por objetivo a coleta de informações que irão subsidiar a eventual responsabilização penal do autor dos fatos, tem-se que a atividade desenvolvida pela polícia é auxiliar ao Ministério Público e ao Poder Judiciário. Esta, aliás, a razão pela qual as Polícias Civis dos Estados e do Distrito Federal e a Polícia Federal, no exercício dessa atividade, vêm a ser denominadas polícia judiciária.

Compreendendo o trabalho de reconstituição do fato como uma verdadeira ciência, é necessário que, para que tenha valor como prova, esteja sistematizado. Eis, portanto, que o próprio Código de Processo Penal estabelece a necessidade de que esteja esse procedimento e as peças a ele correspondentes reduzido a forma escrita ${ }^{11}$. Ou, como prefere Francisco Sannini Neto:

Conforme mencionado na introdução, o sistema de investigação preliminar é essencial à posterior fase processual, possibilitando a produção de provas e elementos de informação que subsidiam todas as partes envolvidas nesta fase da persecução penal. Vale lembrar que, com relação às infrações penais, o Brasil adotou o inquérito policial como meio para se formalizar tais investigações preliminares (SANNINI NETO, 2004, p. 54).

${ }^{11}$ Art. 9o do Código de Processo Penal (BRASIL, 1941). 
Exige-se, até como forma de possibilitar a defesa do acusado, esteja o raciocínio empreendido pela autoridade policial no tocante à atribuição da culpa descrito em um procedimento escrito, especificamente instaurado para aquela finalidade. Essa justamente é a essência e o objetivo do Inquérito Policial, finalidade maior da atividade de polícia judiciária, e que, no entender de Dilermando Queiroz Filho, pode assim ser conceituado:

O Inquérito Policial é o instrumento pelo qual o Delegado de Polícia materializa a investigação criminal, compila informações a respeito da infração penal, de suas circunstâncias e resguarda provas futuras, que poderão ser utilizadas em juízo contra o autor do delito (QUEIROZ FILHO, 2000, p. 46).

Procedimento essencial para o deslinde da verdade, a doutrina processualista penal e a própria legislação são praticamente uníssonas em defender a dispensabilidade desse procedimento, desde que o Ministério Público, por óbvio, disponha de outros elementos de convicção ${ }^{12}$. A esse respeito, o Manual de Polícia Judiciária da Polícia Civil do Estado de São Paulo assim se posiciona:

O Inquérito Policial, instituto altamente democrático, mantidos os seus pressupostos básicos pela atual Constituição Federal, há mais de um século, vem servindo como instrumento hábil contra acusações levianas e precipitadas das quais a razão humana pode se valer como meio de desvio comportamental. Por outro lado, é o Inquérito Policial fundamento da quase totalidade das denúncias formuladas pelo Ministério Público contra aqueles apontados pela autoridade policial como autores de infrações penais e que, portanto, devem ser levados às malhas da Justiça (QUEIROZ, 2007, p. 31).

Entendidos os conceitos e a utilidade do Inquérito Policial, cumprenos analisar a sua forma de instauração. Até porque, é especificamente sobre uma delas que recai o objetivo deste estudo.

12 Confira-se, a propósito, os artigos 39, parágrafo 5o e 46, parágrafo 1o do Código de Processo Penal (BRASIL, 1941). 
A prática do delito, como se viu, faz instaurada a persecução penal que tem como fase preliminar a investigativa, a qual se materializa, por regra, pela via do Inquérito Policial. São variadas as formas de se dar início a esse procedimento, todas elas estabelecidas em lei ${ }^{13}$. A primeira delas diz respeito às hipóteses de crimes de ação penal pública, e se exterioriza por intermédio da portaria da autoridade policial. Esse é o ato administrativo pelo qual o delegado de polícia, no exercício de suas atividades rotineiras, acaba por tomar ciência da ocorrência de um fato aparentemente criminoso, e, havendo elementos mínimos a indicar quem seja seu autor, sempre de forma fundamentada, dá início à atividade investigativa.

Em outros casos, o conhecimento que se tenha acerca do fato chega, num primeiro momento, não ao delegado de polícia, mas ao juiz de direito e ao promotor de justiça, os quais, a partir daquele requisitarão a instauração do competente procedimento investigatório. Nesses casos, a autoridade policial, entendendo pela efetiva ocorrência do delito, instaura o inquérito policial com base naquela manifestação.

Embora de raríssima ocorrência prática, cabe mencionar que, no ordenamento jurídico brasileiro, também o ministro da Justiça possui o poder de requisitar a instauração do inquérito policial. São casos, por exemplo, de crimes cometidos contra a honra do presidente da República e de crime cometidos por estrangeiro contra brasileiro fora do Brasil ${ }^{14}$.

O ofendido ou o seu representante legal são igualmente detentores do direito de requerer a instauração de procedimento investigativo destinado à apuração das circunstâncias do ocorrido. Nesses casos, porém, a lei resguarda certa dose de discricionariedade à autoridade policial quanto à efetiva instauração ou não do inquérito policial ${ }^{15}$.

\footnotetext{
${ }^{13}$ Art. 5o do Código de Processo Penal (BRASIL, 1941).

${ }^{14}$ Art. 7o., parágrafo 3o, alínea b, e art. 145, parágrafo único, ambos do Código Penal (BRASIL, 1940).

15 Importante ressaltar que, em casos em que seja indeferido pela autoridade policial o pedido de abertura de investigação policial, o Código de Processo Penal (BRASIL, 1941), em seu artigo 5o, parágrafo 20 , resguarda ao ofendido ou ao seu representante legal o chamado recurso para o chefe de polícia. Trata-se de providência administrativa de raríssima ocorrência prática.
} 
A última - mas não menos importante - das formas de instauração do inquérito policial diz respeito à prisão em flagrante. Nessas hipóteses, diferentemente do que ocorre nas anteriores, o conhecimento acerca do fato criminoso chega praticamente pronto às mãos da autoridade policial que, com base nessa ciência, procederá à minuciosa análise sobre a legalidade ou não da detenção efetuada, o que equivale dizer, se a condução do pretenso autor dos fatos se deu da forma como determina o ordenamento jurídico vigente.

Uma vez reconhecida a legalidade da detenção, desde que não se vislumbrem hipóteses em que seja assegurado ao acusado o direito de responder solto à imputação que lhe pesa ${ }^{16}$, determinará, por ato próprio, a privação provisória da liberdade do indivíduo ${ }^{17}$. Esse ato da autoridade policial se materializa por meio do auto de prisão em flagrante delito.

As prisões em flagrante ocorrem, em maior número, em sede de plantões policiais. Sabe-se que essa atividade é desenvolvida, como regra, fora do horário de expediente dos estabelecimentos policiais e forenses durante a noite e aos finais de semana e aos feriados - e, portanto, sem que estejam presentes os chamados atores processuais, exceção feita, por óbvio, à autoridade policial e aos seus agentes.

Os indivíduos sujeitos a essas prisões, em geral, pessoas necessitadas - e, portanto, hipossuficientes, econômica e/ou juridicamente se veem sem o necessário respaldo do aparato estatal defensivo, encontrando-se, com isso, entregues à própria sorte.

\footnotetext{
16 Art. 322, do Código de Processo Penal (BRASIL, 1941). Existe forte discussão doutrinária e jurisprudencial versando sobre a possibilidade ou não de a Autoridade Policial, reconhecendo que o agente praticou a conduta acobertado por quaisquer das excludentes de ilicitude, venha a responder solto pela acusação que lhe pesa. Esse tema, porém, merece ser analisado em estudo específico, o que não constitui objeto do presente.

17 Diz-se privação provisória da liberdade do indivíduo, uma vez que a decisão da Autoridade Policial perdura, em regra, pelo prazo de 24 (vinte e quatro) horas, lapso cronológico dentro do qual a prisão da pessoa deve ser levada ao conhecimento do Poder Judiciário, a quem compete analisar, mais uma vez, a legalidade daquela. O magistrado poderá, analisados os autos: relaxar a prisão, quando ilegal; conceder a liberdade provisória ao acusado, com ou sem fiança; ou converter a prisão em flagrante em prisão preventiva. Cabe ser mencionado, neste instante, a questão das audiências de custódia, recentemente implementadas no Estado de São Paulo por meio do Provimento Conjunto número 3 de 22 de janeiro de 2015, da Presidência do Tribunal de Justiça e da Corregedoria Geral da Justiça. Eventuais discussões sobre ela, todavia, não constituem o objeto do presente estudo.
} 
Procurar-se-á demonstrar até que ponto estão essas pessoas alheias ao âmbito de proteção da chamada ampla defesa, cláusula constitucional fundamental que se traduz em uma verdadeira expressão da cidadania. Esse é o objetivo do capítulo seguinte.

\section{A garantia constitucional da ampla defesa: compreensão de seu exato conceito e real abrangência}

Em instante anterior do presente estudo, afirmou-se que, uma vez cientificado o Estado acerca da ocorrência de um fato em princípio criminoso, nasce para aquele ente não apenas a faculdade, mas o dever de determinar a coleta de todos os elementos de informação que possam, de qualquer modo, servir à efetiva demonstração de sua ocorrência - o que equivale ao conceito de materialidade delitiva - e, ainda, a indicação, mesmo que precária, de quem seja o seu provável autor.

O termo precário aqui utilizado serve para indicar que a afirmação definitiva acerca da responsabilidade penal do agente estará condicionada ao trânsito em julgado da sentença penal condenatória proferida após cumpridas todas as etapas do devido processo movido em juízo ${ }^{18}$. Instaurada essa atividade, que recebe o nome de persecução penal - ou persecutio criminis -, estará o Estado autorizado a se valer de todos os meios legais e moralmente legítimos no sentido de demonstrar a veracidade do direito de que afirma ser o titular.

Faz-se imprescindível, portanto, o atendimento de todos os ditames legais a fim de assegurar a validade da prova. Essa atividade estatal, como se viu, materializa-se, num primeiro instante, pela via do inquérito policial, a qual constitui a essência do presente estudo.

\footnotetext{
18 Equivale dizer que é apenas a partir da segunda fase da persecução penal, a da ação penal, em que o Estado terá exercido efetiva e definitivamente, o seu direito constitucional de ação.
} 
Tal procedimento administrativo, destinado à preliminar coleta dos elementos de conviç̧ão que servirão como base à futura - embora eventual ação penal, assume, no ordenamento jurídico brasileiro, a forma escrita.

As razões que levaram o legislador infraconstitucional a assim proceder indicam pela necessidade de que fosse assegurado, também a esse instrumento, ao nosso ver, a feição democrática assumida pelo Estado brasileiro, especialmente no que tange à observância da garantia constitucional da ampla defesa.

É verdade que a condução dos atos do inquérito policial compreende atividade própria dos órgãos estatais. Trata-se de atribuição que afeta, como vimos, às Polícias Civis dos Estados e do Distrito Federal e da Polícia Federal. Importando a ação desses órgãos, ainda que não em caráter definitivo, a atribuição de responsabilidade penal pelo fato delituoso praticado, necessário que seja dado ao particular, num primeiro instante, o direito de conhecer as razões que levaram o Estado a concluir pela sua participação no fato a ele imputado. Ou seja, não pode haver atribuição de responsabilidade penal ao particular, sem que lhe seja dado ao menos conhecer a precisa imputação que lhe pesa.

Tem-se, aqui, a exata expressão do princípio constitucional do contraditório, o qual, se, por um lado, possibilita ao Estado o manejo de todos os meios dispostos pela ordem jurídica no sentido de determinar a pronta e a efetiva repressão ao fato criminoso praticado - e, com isso, pacificar o âmbito das relações sociais -, por outro lado, assegura ao particular o direito de se contrapor àquela atividade, ofertando, para tanto, todos os meios de que também disponha no sentido de tentar desconstituir a argumentação trazida em seu desfavor.

Acerca do conceito e da expressão desse tão relevante princípio constitucional, merece ser conferida a obra de André Ramos Tavares: 
Todo o ato ou fato produzido ou reproduzido no processo por qualquer de suas partes deve dar ensejo ao direito da outra de se opor, de debater, de produzir contraprova ou fornecer sua versão, ou intepretação daquele ato ou fato apresentado (TAVARES, 2014, p. 616).

Isso equivale a dizer que, se ao Estado é dado o poder de ação, no sentido da repressão ao delito praticado, ao particular deverá ser sempre assegurada a correspondente reação, essência, aliás, da defesa.

A ação estatal encontrará o seu limite, portanto, no exercício do direito de defesa, o qual, nas palavras de Cândido Rangel Dinamarco, pode ser entendida como:

Defesa é o contraponto negativo do poder de ação, ou seja, ela é o conjunto de poderes e faculdades que permitem ao demandado opor-se à pretensão do autor, pleiteando sua rejeição. $\mathrm{O}$ direito de defesa é exercido mediante todos os atos permitidos ao réu no processo, destinados a trazer elementos ao juiz e convencê-lo a não conceder a tutela pedida pelo adversário. Postas assim, ação e defesa têm muito em comum e são poderes situados rigorosamente $\mathrm{n}$ mesmo plano, considerada a essencial igualdade das partes no processo (DINAMARCO, 2009, p. 306).

Referida garantia encontra no texto constitucional o seu fundamento de validade, assim como ocorre com o direito de ação e o próprio princípio do contraditório $^{19}$.

Quanto à sua extensão, note-se que a Constituição Federal expressamente delimitou o seu âmbito de aplicação, determinando que fosse aquela aplicável tanto em sede judicial - pela via do processo - como extraprocessual - pelo intermédio dos procedimentos administrativos. Essa afirmação encontra séria controvérsia doutrinária e jurisprudencial no que tange aos procedimentos administrativos, em especial, no inquérito policial.

Ao nosso ver, todavia, sem qualquer razão de ser, sobretudo quando considerada a extensão dessa garantia constitucional, a qual, conforme se verá, tem assegurada plena efetividade e aplicabilidade não apenas em sede

${ }^{19}$ Art. 5o., inc. LV, da Constituição Federal (BRASIL, 1988). 
de investigação preliminar, mas em todo e em qualquer procedimento administrativo.

Confira-se, a propósito, os ensinamentos contidos na obra de Uadi Lammêgo Bulos:

\begin{abstract}
Preceitua o art. 5o., LV, da Carta Magna: "aos litigantes, em processo judicial ou administrativo, e aos acusados em geral são assegurados o contraditório e a ampla defesa, com os meios e recursos a ela inerentes. Eis a consagração explícita dos princípios do contraditório e da ampla defesa, os quais se dirigem, indistintamente, aos acusados em geral [...] Princípio da ampla defesa é o que fornece aos acusados em geral o amparo necessário para que levem ao processo civil, criminal ou administrativo os argumentos necessários para esclarecer a verdade, ou, se for ou caso, facultar-lhes calar-se, não produzindo provas contra si mesmos (BULOS, 2007, p. 533-534).
\end{abstract}

Perceba que, especificamente no que diz respeito ao exercício do direito de defesa, o texto constitucional não apenas admitiu que fosse ela observada em sede de procedimento administrativo e judicial, como também não estabeleceu em relação a ela qualquer forma de limitação. Ao contrário, exigindo-se que esteja ela circunscrita aos estritos limites da legalidade e da legitimidade das provas, determina que seja ela manejada da forma mais ampla possível ${ }^{20}$.

Acerca da amplitude do exercício da mencionada garantia constitucional, Vicente Greco Filho afirma que:

\begin{abstract}
Consideram-se meios inerentes à ampla defesa: a) ter conhecimento claro da imputação; b) poder apresentar alegações contra a acusação; c) poder acompanhar a prova produzida e fazer contraprova; d) ter defesa técnica por advogado, cuja função, aliás, agora é essencial à Administração da Justiça (art. 133); e) poder recorrer da decisão desfavorável (GRECO FILHO, 1989, p. 110) ${ }^{21}$.
\end{abstract}

\footnotetext{
${ }^{20}$ Ressalte-se que, em relação ao Tribunal do Júri, o texto constitucional determina seja a defesa não apenas ampla, mas plena. É o que estabelece o artigo 5o., inciso XXXVIII, a, da Constituição Federal (BRASIL, 1988).

${ }^{21}$ Sobre a citação feita pelo autor, esclareça-se que o dispositivo invocado diz respeito ao artigo 133, da Constituição Federal (BRASIL, 1988).
} 
Analisando-se a ideia proposta pelo autor, tem-se que o exercício do direito de defesa possui duplo alcance, dizendo a respeito à própria pessoa do acusado. Este, uma vez cientificado da imputação que lhe pesa, poderá se valer do seu direito de ser ouvido, em juízo ou fora dele, de modo a contraditar pessoalmente a argumentação expendida em seu desfavor. Temse, aqui, a expressão do chamado direito de audiência ou autodefesa, acerca da qual ressalta Antonio Scarance Fernandes:

\begin{abstract}
A autodefesa, de que aqui se cuida, é aquela exercida pelo próprio acusado, em momentos fundamentais do processo, não a que é patrocinada por advogado em seu próprio benefício, quando acusado em processo criminal [...]. Esse direito se manifesta no processo de várias formas: direito de audiência, direito de presença, direito a postular pessoalmente. $\mathrm{O}$ direito de audiência consiste no direito que tem o acusado de, pessoalmente, apresentar ao juiz da causa a sua defesa. Isso se manifesta por meio do interrogatório, sendo este o momento adequado para o acusado, em contato direto com o juiz, trazer a sua versão a respeito do fato da imputação (FERNANDES, 2010, p. 263).
\end{abstract}

A despeito da relevância que se possa outorgar a essa defesa, a verdade é que nem todos os acusados estarão necessariamente aptos a manejá-la.

Não deve ser esquecido que grande parte da população se encontra alheia à realidade legislativa, em especial a criminal, desconhecendo detalhes mínimos da legislação vigente, o que poderia incidir de modo considerável na solução de seu caso. O Estado, por outro lado, é composto, em regra, por agentes altamente qualificados e especializados na solução das complexas questões postas à sua análise.

É nítida, portanto, a inobservância da necessária paridade de armas entre as partes envolvidas no litígio penal, algo com que não se coaduna o ordenamento jurídico vigente, declarado viés democrático.

Assim, passa a ser imprescindível a defesa realizada por um profissional do Direito, como garantia constitucional da ampla defesa, a qual, por assegurar a plena igualdade das partes no transcorrer do processo ou do 
procedimento, não poderá ser renunciada pelo acusado. É tamanha a envergadura dessa vertente do princípio da ampla defesa, que o próprio ordenamento jurídico assegura expressamente a primazia de o próprio acusado indicar, por ocasião de sua oitiva - oportunidade em que será manifestada a sua autodefesa -, quem seja o seu defensor, sendo que, em caso de assim não proceder, estará o Estado obrigado a nomear alguém que o faça ${ }^{22}$.

Deve ser lembrado, também, o entendimento adotado pelo Supremo Tribunal Federal quando da adoção da Súmula 523: "No processo penal, a falta de defesa constitui nulidade absoluta, mas a sua deficiência só o anulará se houver prova de prejuízo para o réu" (BRASIL, 1969).

Estabelecidas essas premissas, cumpre-nos, mais uma vez, atentar para a realidade observada no transcorrer dos plantões policiais, especialmente no que tange no momento da elaboração do auto de prisão em flagrante.

Nesses casos, sabedores de que a grande maioria do público afeto ao atendimento realizado nas dependências das delegacias de polícia, em horário em que não mais funciona o expediente forense, é hipossuficiente desconhecendo, por completo os trâmites legais ou, conhecendo, não é detentor da habilitação detida pelo aplicador e pelo operador do direito -, faz-se necessário ao menos questionar até que ponto a ausência de um defensor público naquelas repartições públicas estaria a afrontar a garantia constitucional da ampla defesa.

4. A defensoria pública e o importante papel a ser por ela desempenhado na plena efetivação da garantia constitucional da ampla defesa

Com certa dose de resistência por parte da doutrina e da jurisprudência, tentou-se defender, até este instante, a necessidade de que, não apenas em sede de processo judicial, mas também no transcorrer do procedimento administrativo - em especial do inquérito policial -, sejam

22 Art. 261, do Código de Processo Penal (BRASIL, 1941). 
manifestados, na integralidade, os princípios constitucionais do contraditório e da ampla defesa. O primeiro deles assegura a ambas as partes da relação jurídica controvertida o prévio conhecimento acerca dos argumentos sobre os quais se funda o direito que invocam. $\mathrm{O}$ segundo enseja tanto o direito de ser ouvido na fase procedimental adequada como o de se contrapor aos fatos invocados em seu desfavor, possibilitando, com isso, sejam acolhidas as suas razões.

Não sendo desconsiderado o valor que deva ser assegurado à defesa pessoal do acusado, é sobre a imprescindibilidade do direito de reação que se funda este estudo.

Os crimes constituem uma realidade do cotidiano brasileiro. Costuma-se afirmar, a propósito, que a incidência criminal cresce em progressão geométrica, enquanto os meios de assegurar a sua repressão obedecem à progressão aritmética. Uma rápida visita ao sítio eletrônico da Secretaria de Estado dos Negócios da Segurança Pública do Estado de São Paulo, a título exemplificativo, corroboram essa afirmação (SECRETARIA DE ESTADO DOS NEGÓCIOS DA SEGURANÇA PÚBLICA DA ESTADO DE SÃO PAULO, 2015) ${ }^{23}$.

Nasce, para o Estado, portanto, a necessidade de pronta atuação frente à criminalidade. Tudo como forma de assegurar a já mencionada pacificação social. Grande parte dessa ação empreendida pelo Estado é protagonizada pela polícia, e é especialmente exercida em sede de plantões policiais distribuídos nos mais diversos rincões do país.

Considerado o fato de que essa atividade é desempenhada, no mais das vezes, no período noturno e aos finais de semana e feriados, períodos em que não funciona o chamado expediente forense, a verdade é que, muitos dos acusados que se veem imersos na realidade dos plantões policiais, seja por não conhecerem a legislação penal e processual, seja por conhecê-la de forma

\footnotetext{
${ }^{23}$ No presente estudo, fez-se referência às estatísticas criminais do Estado de São Paulo, uma vez que, em relação a outros estados,Estados esses dados nem sempre estão disponíveis.
} 
deficiente, acabarão por se verem prejudicados quanto ao exercício da ampla defesa, analisada sob o prisma da defesa técnica.

Passa a ganhar relevo, nesse espaço, o questionamento sobre a atuação dos agentes integrantes da defensoria pública. Essa é a instituição a quem é dotada a atribuição constitucional de zelar, em todos os graus, judicial e extrajudicialmente, pelos direitos individuais e coletivos, de forma integral e gratuita dos necessitados ${ }^{24}$. Por necessitado, entenda-se aquela pessoa que não detenha condições financeiras para custear as despesas do processo ou de um advogado particular sem que seja privada do necessário ao seu sustento e ao de sua família ${ }^{25}$. Essas pessoas, até o advento da Constituição Federal de 1988, eram atendidas por advogados nomeados pelos juízes de direito de cada Comarca, em lista ofertada pela Ordem dos Advogados do Brasil local ${ }^{26}$.

Inspirado por um ideal de cidadania e de plena observância do direito que a todos atinge de acesso à justiça, o legislador constituinte de 1988 determinou a criação das Defensorias Públicas no âmbito da União, dos Estados e do Distrito Federal e dos Territórios.

Assegura-se, por intermédio dessa instituição, que as pessoas economicamente desvalidas possam se socorrer do Poder Judiciário a fim de verem atendidas as suas pretensões, o que é defendido, a propósito, por Cinthia Robert e Elida Seguin:

\footnotetext{
$\mathrm{Na}$ luta pela defesa do Homem algumas Instituições são representativas do patamar de desenvolvimento alcançado. Entre essas, a Defensoria Pública exsurge como um marco da possibilidade de ser garantido ao pobre o Acesso à Justiça e à busca por uma prestação jurisdicional isonômica. O princípio da igualdade entre as partes é densificado pela atuação institucional, fazendo com que uma pessoa não dependa de sua fortuna para ter seus direitos reconhecidos e que se deixe de fazer Justiça em virtude da pobreza do titular do direito (ROBERT; SEGUIN, 2000, p. 8).
}

\footnotetext{
${ }^{24}$ Art. 134, caput, da Constituição Federal (BRASIL, 1988).

25 Art. 2o, parágrafo único da Lei n. 1.060, de 5 de fevereiro de 1950 (BRASIL, 1950).

${ }^{26}$ Art. 5o da Lei n. 1.060, de 5 de fevereiro de 1950 (BRASIL, 1950).
} 
Ainda sobre a relevância das funções prestadas pela defensoria pública, merece análise a lição de Cândido Rangel Dinamarco:

As Defensorias Públicas desempenham funções de redobrado interesse público e utilidade social, dada a necessidade de dar amparo jurídico aos necessitados, para cumprimento de generosa promessa constitucional (assistência juridica integral - Const., art. $5^{\circ}$, inc. LXXIV) [...]O pouquíssimo que o Estado faz em cumprimento da promessa constitucional de assistência judiciaria integral restringe-se praticamente à dispensa de custas e taxas judiciárias, sendo insuficiente a oferta de serviços de patrocínio judicial gratuito (Const., art. 5o, inc. I - infra, nn. 764-770 ss.). Esses serviços vinham sendo prestados pelas Procuradorias dos diversos Estados, e, em alguns lugares, pelo Ministério Público. Visando a institucionalizar sistematicamente tal função em todo o país e dar-lhe dignidade especial, a Constituição Federal incluiu as Defensorias Públicas entre os organismos que exercem funções essenciais à justiça e atribuiu-lhes os encargos naturais a entidades dessa ordem, ou seja, os de orientação e defesa dos necessitados perante órgãos judiciários de todos os graus de jurisdição (art. 134). O binômio orientação e defesa integra o conceito de assistência judiciária integral, incluindo a advocacia consultiva e a forense em prol daqueles que não têm recursos para pagar honorários advocatícios (DINAMARCO, 2009, p. 721-722).

A despeito da importante função que exercem esses profissionais, fato é que os defensores públicos, até este instante, não se fazem presentes nas sedes dos plantões policiais.

Essa situação tem transformado a garantia constitucional da ampla defesa - verdadeira expressão da cidadania - em uma defesa técnica orientada e ofertada apenas em horário comercial, e já em fase judicial do procedimento, mesma oportunidade em que tomam conhecimento da acusação o Poder Judiciário e o Ministério Público.

Assim, as pessoas que se encontram sujeitas aos plantões policiais - em regra pessoas hipossuficientes na exata expressão da lei - têm visto as suas liberdades serem restringidas sem que ao menos lhes seja assegurado o direito de se entrevistarem previamente com a pessoa que virá a representá-las. 
Não devem ser esquecidas, por óbvio, as iniciativas adotadas no sentido de ver assegurada a observância dessa tão comezinha garantia constitucional.

Cabe-nos mencionar, por exemplo, a ação empreendida pela Defensoria Pública do Estado do Rio Grande do Sul no transcorrer do mês de julho de 2014, quando, no período da Copa do Mundo, defensores públicos daquele estado se fizeram presentes nas dependências da Academia Integrada de Segurança Pública, em Porto Alegre, e ali se revezaram em plantões de 24 (vinte e quatro) horas a fim de acompanhar pessoas detidas em flagrante (DEFENSORIA PÚBLICA DO ESTADO DO RIO GRANDE DO SUL, 2015). Os depoimentos prestados pelos próprios defensores públicos que atuaram naquela oportunidade parecem ratificar a posição defendida no presente estudo.

Sobre a importância da presença do defensor público na fase extrajudicial da persecução penal, o defensor público Arnaldo França Quaresma Junior destacou que: "é importante a Defensoria Pública se fazer presente para coibir eventuais violações de direitos humanos e, se verificada alguma situação, agir para cessar ou reparar esse dano posteriormente" (DEFENSORIA PÚBLICA DO ESTADO DO RIO GRANDE DO SUL, 2015).

Note-se a extremada relevância da atuação da Defensoria Pública como forma de assegurar plena efetividade aos direitos e às garantias fundamentais. Ou, como afirmado pelo defensor público Raphael Varella Coelho, quando esclarece que: "a atuação foi marcante por garantir que as pessoas detidas em flagrante tivessem todos os seus direitos assegurados" (DEFENSORIA PÚBLICA DO ESTADO DO RIO GRANDE DO SUL, 2015).

É evidente que a presença da autoridade policial - materializada na figura do delegado de polícia - na sede dos plantões policiais assegura, em larga medida, a observância do preceito constitucional a que se fez menção.

Não deve ser desconsiderado, contudo, que o grande número de casos postos à análise das autoridades policiais no dia a dia das repartições que 
representam pode vir a ensejar eventuais afrontas aos direitos do indivíduo que vier a ser preso em flagrante.

Eventuais irregularidades do procedimento extrajudicial, pela ausência dos defensores públicos já no instante da elaboração, especialmente dos autos de prisão em flagrante, apenas poderão ser sanadas na fase processual, em nítida afronta, pois, aos interesses de seus representados.

Acerca disso, o defensor público Wilian Gonçalves Bolfoni conclui que:

\begin{abstract}
Foi uma experiência valiosa, pois consistiu em uma atuação na fase pré-judicial, trazendo uma rotina diferente do cotidiano da comarca. A presença do Defensor Público no momento do flagrante efetiva garantias constitucionais e evita, muitas vezes, excesso de imputação delitiva ao flagrado (DEFENSORIA PÚBLICA DO ESTADO DO RIO GRANDE DO SUL, 2015).
\end{abstract}

Iniciativas como a descrita são extremamente válidas, contudo meramente pontuais. Não é difícil perceber que aquelas foram motivadas tão somente pela realização de evento de grandes proporções aqui realizado, a saber, a Copa do Mundo.

É preciso fortalecer a ideia no sentido de que a presença desses profissionais também nas sedes dos plantões policiais, tem por finalidade assegurar ao acusado plenas condições de exercer o seu direito de defesa na exata extensão do que determina a Constituição Federal. Essa não é uma tarefa fácil, sobretudo quando considerada a exigência de tempo e de maciços investimentos por parte dos estados na, ainda incipiente carreira de defensor público, a qual, em muitos deles, ainda se encontra em vias de ser implementada.

Considerado o quadro de defensores públicos em atividade atualmente, é bem possível concluir que seria inviável o atendimento do que ora se propõe. Confirma essa afirmação a análise dos dados extraídos do III Diagnóstico Defensoria Pública no Brasil, elaborado no ano de 2009, pelo Ministério da Justiça. Vislumbra-se, pelos gráficos ali apresentados, que o 
número total de defensores públicos em atividade, em todo o território nacional, era de apenas 7.177 (sete mil cento e setenta e sete) (MINISTÉRIO DA JUSTIÇA, 2015).

No que tange ao aspecto numérico, tem-se que uma das soluções possíveis seria a de se estabelecer convênios entre as defensorias públicas estaduais e a Ordem dos Advogados do Brasil, no sentido de ofertar esse serviço em caráter imediato à população mais carente.

Em caráter mediato, contudo, cumprirá a cada um de nós exigir, dos poderes públicos, a adoção das providências que garantam o acesso à justiça àqueles que efetivamente necessitem, assegurando-se-lhes o exercício da plena cidadania.

\section{Considerações finais}

Este trabalho teve como objetivo analisar a precisa extensão do princípio constitucional da ampla defesa e a sua efetivação prática, sobretudo no que toca à fase preliminar da persecução penal. Como forma de ao menos demonstrar que, embora se procure atribuir excessivo valor ao direito de audiência que tem o acusado no transcorrer daquela etapa, é sob a ótica da defesa técnica que aquela garantia se manifestará em sua plenitude.

Corrobora essa conclusão o fato de que o acusado poderá, inclusive, abrir mão da sua autodefesa, enquanto, em relação à defesa técnica, essa disponibilidade não é autorizada, chegando o Supremo Tribunal Federal a defender a nulidade absoluta do processo quando ausente aquela.

Ocorre, porém, que a despeito da importância que tenha, fato é que a ausência dos defensores públicos nas sedes dos plantões policiais tem causado graves prejuízos aos seus representados. Esses, pessoas hipossuficientes na acepção jurídica e econômica do termo, acabam por não ter o seu caso submetido previamente àqueles a quem competirá as suas defesas. 
A fim de que fosse atingido o objetivo pretendido, iniciou-se o estudo com a análise acerca do crime. Definiu-se que esse é, na verdade, um fato eminentemente derivado da vida em sociedade, mas que necessitará ser combatido, a fim de possibilitar o pleno desenvolvimento do corpo social, instabilizado pela sua prática.

Como forma de evitar a justiça privada, porém, o Estado avoca para si a responsabilidade de perseguir o delito e de impor ao delinquente, por conseguinte, a pena correspondente à sua conduta. Tal atividade se manifesta por intermédio da persecução penal.

Essa, por sua vez, se desenvolve em duas fases. A primeira delas compreende a fase investigativa, na qual serão colhidos os elementos mínimos que ensejarão a segunda, a via processual, pela qual o Estado reconhece, em caráter definitivo, se os elementos ali colhidos se mostram suficientes a fundamentar a condenação. Esse foi o objetivo do segundo capítulo.

No terceiro, procurou-se evidenciar o próprio princípio constitucional da ampla defesa e a sua relevância em face do caráter democrático assumido pelo Estado brasileiro, principalmente a partir do advento da Constituição Federal de 1988.

Estabeleceu-se que a atividade estatal somente será adequadamente prestada se for dada aos seus órgãos a prerrogativa de agir sempre que cometido o delito, como também quando plenamente assegurada ao acusado a efetiva possibilidade de ofertar a correspondente reação.

Concluiu-se que essa defesa do acusado, na maioria das vezes, não é observada por ocasião dos plantões policiais, especialmente quando consideradas as peculiaridades do público que a eles se encontra sujeita. Este, no mais das vezes, constituído por pessoas pobres, acabam deixados à sua própria sorte, pelo simples fato de não disporem do numerário suficiente para custear a sua defesa.

Considerando-se a inspiração democrática do texto constitucional, não se afigura adequado que a defesa de quem quer que seja venha a ser 
relegada a plano secundário. É preciso, a qualquer custo, assegurar aos indivíduos - especialmente aos das camadas mais necessitadas da população - uma forma de acesso à justiça. Foi isso, aliás, que orientou a criação das Defensorias Públicas, órgãos constitucionalmente detentores dessa tão relevante missão.

Ocorre, contudo, que tal atribuição tem se mostrado meramente retórica no que tange ao procedimento do inquérito policial. Não se desconsidera a importância dessa instituição e nem do trabalho por ela realizado até este instante em outras áreas do direito.

Poder-se-ia invocar, como justificativa, o fato de as defensorias públicas não contarem, atualmente, com o número de profissionais necessários a se desincumbirem desse mister.

Essa questão não passou ao largo no presente estudo, tendo sido sugerida, ao menos por ora, a elaboração de termos de convênios entre as defensorias públicas estaduais e a Ordem dos Advogados do Brasil, no sentido de ofertar, de imediato, esse serviço. Tal se afigura, por ora, a solução mais adequada - embora não ideal - a efetivar, ao menos num nível mínimo, a garantia constitucional da ampla defesa em sede de persecução penal, a qual segue, por enquanto, constantemente afrontada.

\section{Referências}

ABBOUD, Georges, CARNIO, Henrique Garbellini; OLIVEIRA, Rafael Tomaz de. Introdução à teoria e à filosofia do direito. $3^{\text {a }}$ ed. São Paulo: Revista dos Tribunais, 2015.

ALMEIDA, Joaquim Canuto Mendes de. Princípios fundamentais do processo penal. São Paulo: RT, 1973.

BANDEIRA DE MELlO, Celso Antonio. Curso de Direito Administrativo. São Paulo: Malheiros Editores, 2009.

BRASIL. Constituição da República Federativa do Brasil. Brasília, DF: Senado Federal, 1988.

.Decreto-lei n. 2.848, de 7 de dezembro de 1940. Código Penal. Disponível em: <http://www.planalto.gov.br/ccivil_03/decreto-lei/Del2848compilado.htm>. Acesso em: 07 dez. 2015. 
BRASIL. Decreto-lei n. 3.689, de 3 de outubro de 1941. Código de Processo Penal. Disponível em: <http://www.planalto.gov.br/ccivil_03/decreto-lei/Del3689.htm>. Acesso em: 07 dez. 2015.

. Lei n. 1.060, de 5 de fevereiro de 1950. Estabelece normas para a concessão de assistência judiciária aos necessitados. Disponível em: < http://www.planalto.gov.br/ccivil_03/LEIS/L1060.htm>. Acesso em: 07 dez. 2015.

. Lei n. 12.850, de 2 de agosto de 2013. Dispõe sobre a investigação criminal conduzida pelo delegado de polícia. Disponível em: $<$ http://www.planalto.gov.br/ccivil_03/_ato2011-2014/2013/lei/112830.htm>. Acesso em: 07 dez. 2015.

. Supremo Tribunal Federal. Súmula n. 523: No processo penal, a falta da defesa constitui nulidade absoluta, mas a sua deficiência só o anulará se houver prova de prejuízo para o réu. Data de publicação do enunciado: DJ de 12.12.1969. Disponível em: $<$ http://www.stf.jus.br/portal/cms/verTexto.asp?servico=jurisprudenciaSumula\&p agina=sumula_501_600> $>$. Acesso em: 07 dez. 2015.

BULOS, Uadi Lammêgo. Curso de direito constitucional. São Paulo: Saraiva, 2007.

CARVAlHO FILHO, José dos Santos. Manual de Direito Administrativo. Rio de Janeiro: Lumen Juris, 2009.

DEFENSORIA PÚBLICA DO ESTADO DO RIO GRANDE DO SUL. Plantão da Defensoria Pública na Acisp chega ao fim com avaliação positiva. Disponível em: < http://www.defensoria.rs.gov.br/conteudo/22023>. Acesso em: 07 dez. 2015.

DINAMARCO, Cândido Rangel. Instituições de direito processual civil. $6^{a}$ ed. São Paulo: Malheiros Editores, 2009.

FERNANDES, Antonio Scarance. Processo penal constitucional. São Paulo: Saraiva, 2010.

FILOCRE, Lincoln D’Aquino. Direito de segurança pública: limites jurídicos para políticas de segurança pública. Coimbra: Almedina, 2010.

GRECO FILHO, Vicente. Tutela constitucional das liberdades. São Paulo: Saraiva, 1989.

MARINONI, Luiz Guilherme; ARENHART, Sérgio Cruz. Curso de processo civil processo de conhecimento. v. 2. $6^{\text {a }}$ ed. São Paulo: Revista dos Tribunais, 2007.

MINISTÉRIO DA JUSTIÇA. III Diagnóstico Defensoria Pública no Brasil. Disponível em: <http://www.defensoria.sp.gov.br/dpesp/repositorio/0/III Diagnóstico Defensoria Pública no Brasil.pdf>. Acesso em: 07 dez. 2015.

MORAES, Alexandre de. Direito constitucional. 27 ed. São Paulo: Atlas, 2011.

PEDROSO, Fernando de Almeida. Direito penal parte geral: doutrina e jurisprudência. v. 1. $4^{\text {a }}$ ed. São Paulo: Método, 2008.

QUEIROZ,Carlos Alberto Marchi de (Coord.). Manual de Polícia Judiciária: doutrina, modelos. $5^{\text {a }}$ ed. São Paulo: Delegacia Geral de Polícia, 2007.

QUEIROZ FILHO, Dilermando. Manual de inquérito policial. Rio de Janeiro: Adcoas, 2000.

RANGEL, Paulo. Direito processual penal. 21 a ed. São Paulo: Atlas, 2013.

ROBERT, Cinthia; SEGUIN, Elida. Direitos Humanos, acesso à justiça: um olhar da defensoria pública. Rio de Janeiro: Editora Forense, 2000. 
SANNINI NETO, Francisco. Inquérito policial e prisões provisórias: teoria e prática de polícia judiciaria. $1^{a}$ ed. São Paulo: Ideias \& Letras, 2004.

SECRETARIA DE ESTADO DOS NEGÓCIOS DA SEGURANÇA PÚBLICA DA ESTADO DE SÃO PAULO. Indicadores da criminalidade do Estado de São Paulo. Disponível em: <http://www.ssp.sp.gov.br/novaestatistica/default.aspx >. Acesso em: 07 dez. 2015.

TAVARES, André Ramos. Curso de direito constitucional. $12^{a}$ ed. São Paulo: Saraiva, 2014.

TÁVORA, Nestor; ALENCAR, Rosmar Rodrigues. Curso de direito processual penal. $3^{\text {a }}$ ed. Salvador: JusPODIVM, 2009. 